\title{
Raw Materials of the Far Eastern Region are a Valuable Source of Micronutrients In Human Nutrition
}

\author{
Frolova N.A. \\ Amur State University \\ Blagoveshchensk, Russia \\ ninelfr@mail.ru
}

\author{
Reznichenko I. Y. \\ Kemerovo State University \\ Kemerovo, Russia \\ Irina.reznichenko@gmail.com
}

\begin{abstract}
The article proposes a complex scheme of processing of fruit and berry and animal raw materials as a valuable source of physiologically valuable ingredients in human nutrition. The chemical composition of the powder of reindeer antlers and juice and phyto-powders of berries, cranberries was carried out according to standard conventional methods. The work investigated the chemical composition of the juice, berries and antlers powder, which allowed to detect a wide range of physiologically valuable ingredients remaining in vitamins, phospholipids, polyphenol substances, the introduction in the formulation of foods which would contribute to the detected elements. The proposed scheme of processing of plant and animal raw materials can be recommended for introduction into the production process for the purpose of waste-free production. Data on experimental substantiation of increase of nonspecific resistance of rats due to the use of confectionery products with introduction of the offered berries and animal raw materials are presented.
\end{abstract}

Keywords - berries, antlers, juice, processing, phytochemicals, chemical composition, rats, experimental animals.

\section{INTRODUCTION}

Among the reasons for the decline in the quality of life of the population and the development of a number of diseases are such as the consumption of food products with low consumer properties, including unreasonably high calorific value, reduced nutritional value, excess saturated fat, deficiency of micronutrients and dietary fibers [1-3]. The objectives of the adopted strategy are to ensure the quality of food products, to promote and stimulate the growth of demand and supply for better food products and to ensure compliance with the rights of consumers to purchase such products.

Amur region of the far Eastern region of Russia contains a wide range of representatives of fruit and berry raw materials, including vibúrnum ópulus berries (Vibúrnum ópulus), blueberries (Vaccínium uliginósum) and cranberries (Vaccinium vitis idaea), which contain vitamin A (carotene), B1 (thiamine), B6 (folic acid), C (ascorbic acid), K (potassium), group of p-active substances [4-6] in addition, berries contain flavonoids, organic acids and minerals (iron, calcium, manganese, phosphorus) [7-9].
Promising raw materials of animal origin are reindeer antlers, which are classified as waste [10]. In the North of the region there are numerous reindeer farms with thousands of reindeer (Rangifer tarandus) in their farmstead. It is proved that reindeer antlers have anti-stress, tonic and immunostimulating effect, which becomes more important in the production of functional foods [11-13].

The use of plant and animal raw materials in confectionery technology can not only increase the biological value of finished products, but also the exclusion from the formulation of synthetic dyes and flavors due to specific organoleptic characteristics, including taste and color [14-15].

\section{THE OBJECTS AND METHODS OF RESEARCH}

The object of research was the fruit and berry raw materials-viburnum berries, blueberries and cranberries, as well as juice and phyto powder obtained from berries. Reindeer antlers were chosen as animal raw materials. The content of vitamin $\mathrm{C}$ in the berries and vitaprost was determined by the method based on the extraction of vitamin $\mathrm{C}$ with a solution of phosphoric acid followed by titration with a solution of 2.6 dichlorphenolindophenol sodium. Determination of hydroxycinnamic acids was carried out by spectrophotometry, tannins - titrimetric.. Determination of vitamins B1,B2, B6 was carried out by fluorometric method. Determination of vitamin E was carried out by differential voltammetry. Phospholipids were analyzed by onedimensional micro-TLC, for using standard plates on Silufol and solvent system: chloroform-methanol-ammonia (112:48:28), the detector - water. The content of polyphenolic substances by precipitation of polygalacturonic acid and hydrolysis in the form of calcium pectate.

\section{RESEARCH RESULTS AND DISCUSSION}

Processing of plant and animal raw materials is gaining more and more significant momentum among manufacturers. Waste obtained during processing is a promising material for further use, especially if they contain valuable biologically active substance [16-17]. In the course of the research, a "non-Specialized process" of updating the complex processing of raw materials for confectionery products was proposed, 
presented in figure 1, including the selection of the raw material base of the Amur region, individual options for extracting physiologically valuable ingredients from the selected raw materials (extraction, drying, grinding, pressing, etc.), processing of waste remaining after extraction and subsequent use of raw materials and waste in confectionery products for functional nutrition (Fig.1).

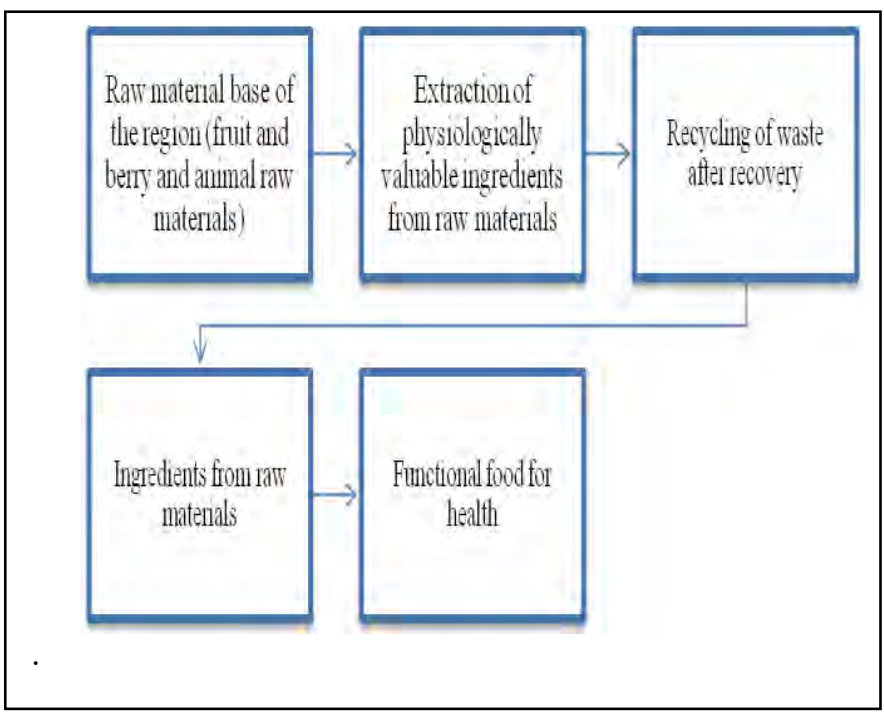

Fig. 1. "Non-specialized process" of updating of complex processing of raw materials.

Berry picking was held in 2017. Berries were gathered in the Annunciation district in July, berries cranberries in the Zeya district in late August-early September, the berries of blueberry in Selemdzinski area in mid-July. Canned reindeer antlers are provided by the reindeer husbandry of Tynda district of the Amur region. Analysis of microbiological indicators of harvested berries and reindeer antlers indicate that the original plant and animal raw materials meet The requirements of the technical regulations of the Customs Union 021/2011 "On food safety", therefore, can be used in the confectionery industry. Before receiving the juice berries were inspected, which is the selection of whole, cleared of impurities berries.

According to the scheme of complex processing of plant and animal raw materials, shown in figure 2 berries of viburnum, cranberries and blueberries are treated with water at a temperature of $25-280 \mathrm{C}$ for 2 minutes, then dried at a temperature of $18-220 \mathrm{C}$ for 30 minutes. Extraction of juice from berries is carried out by juicer separately [9], after which the pulp of berries of viburnum, blueberries and cranberries, remaining after extraction of juice is dried at a temperature of $35-400 \mathrm{C}$ for 30 minutes, then crushed to a particle diameter of $0.01 \sim 0.04 . \mathrm{mm}$.

This scheme, differs by additional drying of the pulp of berries of viburnum, cowberry, blueberry and grinding to a particle powder with a particle diameter of 0.01-0.04 mm. After extracting the juice from the berries and obtaining the powder and powder from the pant, studies were carried out on the chemical composition of the biologically active substances (table 1).
TABLE I. THE CONTENT OF BIOLOGICALLY ACTIVE SUBSTANCES IN THE JUICE AND PLANT POWDER OF PHYTOPLANKTON $(\mathrm{X} \pm \mathrm{M} ; \mathrm{P} \leq 0,05)$

\begin{tabular}{|l|c|c|c|}
\hline Berries & $\begin{array}{c}\text { Tannins, } \\
\%\end{array}$ & $\begin{array}{c}\text { Hydroxycinnamic } \\
\text { acids, \% }\end{array}$ & $\begin{array}{c}\text { Polyphenolic } \\
\text { substances, \% }\end{array}$ \\
\hline \multicolumn{4}{|c|}{ Berry juice: } \\
\hline viburnum & $4.84 \pm 0.2$ & $0.354 \pm 0.004$ & $1.124 \pm 0.002$ \\
\hline cowberry & $4.28 \pm 0.4$ & $0.342 \pm 0.002$ & $0.982 \pm 0.002$ \\
\hline blueberry & $2.42 \pm 0.2$ & $0.238 \pm 0.003$ & $1.040 \pm 0.004$ \\
\hline \multicolumn{4}{|c|}{ Fiberglass: } \\
\hline viburnum & $0.86 \pm 0.08$ & $0,012 \pm 0.004$ & $0.044 \pm 0.002$ \\
\hline cowberry & $0.48 \pm 0.10$ & $0.024 \pm 0.002$ & $0.012 \pm 0.001$ \\
\hline blueberry & $0.74 \pm 0.09$ & $0.020 \pm 0.001$ & $0.008 \pm 0.001$ \\
\hline
\end{tabular}

The greatest content of tannic and polyphenolic substances was found in the viburnum, while the berries of the cowberry are not much inferior to the berries of the viburnum only by $0.56 \%$ and $0.012 \%$. Fennel of the berries of viburnum also contains more tannic substances, hydroxyric acids and polyphenolic substances, which, of course, is due to the chemical composition of the feedstock.

Vitamins of group B act as a coenzyme and promote the release of energy of carbohydrates, proteins and fats, especially when it comes to foods with high energy value. Therefore, it was of interest to find out the content of vitamins and vitamin-like compounds in berries of viburnum, magnolia vine and grapes (table 2,3).

TABLE II. THE CONTENT OF VITAMINS IN JUICE AND FRUIT POWDER OF BERRIES OF VIBURNUM, COWBERRY AND BLUEBERRIES $(\mathrm{X} \pm \mathrm{M} ; \mathrm{P} \leq 0,05)$

\begin{tabular}{|l|c|c|c|}
\hline \multirow{2}{*}{ Berries } & \multicolumn{3}{|c|}{ Vitamins, mg / 100g } \\
\cline { 2 - 4 } & $B_{1}$ & $B_{2}$ & $B_{6}$ \\
\hline \multirow{3}{*}{ viburnum } & $0.030 \pm 0.002$ & $0.015 \pm 0.003$ & $0.032 \pm 0.004$ \\
\hline cowberry & $0.022 \pm 0.001$ & $0.010 \pm 0.002$ & $0.020 \pm 0.002$ \\
\hline blueberry & $0.010 \pm 0.003$ & $0.008 \pm 0.001$ & $0.024 \pm 0.001$ \\
\hline & & Fiberglass: & $0.010 \pm 0.01$ \\
\hline viburnum & $0.010 \pm 0.001$ & $0.008 \pm 0.02$ & $0.010 \pm 0.03$ \\
\hline cowberry & $0.014 \pm 0.002$ & $0.004 \pm 0.01$ & $0.0105 \pm 0.02$ \\
\hline blueberry & $0.013 \pm 0.001$ & $0.002 \pm 0.03$ & \\
\hline
\end{tabular}

The maximum content of vitamins $\mathrm{B}_{1}, \mathrm{~B}_{2}, \mathrm{~B}_{6}$ is noted in the berries of viburnum. Berries of blueberries on the content of vitamin $B_{1}$ are three times inferior to the berries of viburnum.

A high content of ascorbic acid is also noted in the berries of viburnum, which characterizes the more acidic taste of berries. The minimum value of ascorbic acid content was determined in blueberry berries to be $53.2 \pm 0.2 \mathrm{mg} / 100 \mathrm{~g}$.

Berries cranberries in the content of vitamin $\mathrm{E}$ are superior to other berries. 
TABLE III. THE CONTENT OF VITAMINS IN JUICE AND FRUIT POWDER OF BERRIES OF VIBURNUM, COWBERRY AND BLUEBERRIES $(\mathrm{X} \pm \mathrm{M} ; \mathrm{P} \leq 0,05)$

\begin{tabular}{|c|c|c|}
\hline \multirow[t]{2}{*}{ Berries } & \multicolumn{2}{|c|}{ Vitamins, $\mathrm{mg} / 100 \mathrm{~g}$} \\
\hline & $C$ & $E$ \\
\hline \multicolumn{3}{|c|}{ Berry juice: } \\
\hline viburnum & $86.2 \pm 0.4$ & $0.42 \pm 0.12$ \\
\hline cowberry & $67.8 \pm 0.6$ & $1.66 \pm 0.06$ \\
\hline blueberry & $53.2 \pm 0.2$ & $0.77 \pm 0.10$ \\
\hline \multicolumn{3}{|c|}{ Fiberglass: } \\
\hline viburnum & $42.0 \pm 0.6$ & $0.78 \pm 0.2$ \\
\hline cowberry & $42.8 \pm 0.8$ & $0.86 \pm 0.1$ \\
\hline blueberry & $43.9 \pm 0.4$ & $0.83 \pm 0.2$ \\
\hline
\end{tabular}

In powder from reindeer antlers, the content of phospholipids was studied, among which the following fractions were found: PE-phosphatidylethanolamine, PXphosphatidylcholine, sphingomyelin DP, phosphatidylserine phosphatidylinositol, PK-phosphatidic acid (Table 4).

TABLE IV. T HE CONTENT OF PHOSPHOLIPIDS (PL) IN POWDER REINDEER ANTLERS

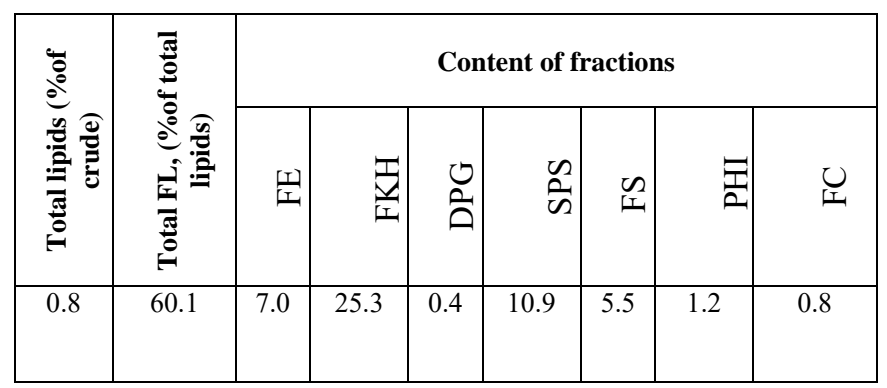

The maximum value of phospholipid fractions contains phosphatidylcholine, which has lipolytic action. Minimum value - diphosphoglycerate, which forms in erythrocytes from 1,3-diphosphoglycerate, intermediate metabolically.

In the course of research on the technology developed by us, samples of iris and dragees were obtained with the introduction of juice from viburnum, blueberries, cowberry and powder from reindeer antlers.

The establishment of the optimal dosage of the introduced juice of berries and powder (at home) in confectionery was made on the basis of technological parameters and commodity indicators of finished products. Technological factors were taken into account for maximum preservation of biologically.

The establishment of the optimal dosage of the introduced juice of berries and powder (at home) in confectionery was made on the basis of technological parameters and commodity indicators of finished products. Technological factors were taken into account for maximum preservation of biologically active substances in the finished product.

To confirm the effectiveness of functional confectionery products, we conducted experiments on rats, during which we studied the effect of the use of iris and dragees with the introduction of berry juice and powder (pulp) antlers adaptive capabilities in cold exposure.

The method with the use of physical activity is one of the common, used to identify the pharmacological value of substances, in which the estimated duration of the load on the background of the systematic use of the products on the formation of a stable adaptation to muscle activity.

At the first stage of studies, the maximum duration of running animals on the tape moving at a speed of $30 \mathrm{~m} / \mathrm{min}$ after 10, 20 and 30 days of consumption of dragees and iris of functional purpose was determined, which were added to the daily diet of $1.5 \mathrm{~g}$, respectively, 3 times a day (table 5).

TABLE V. DURATION OF RUN OF RATS ON A TAPE AGAINST THE USE OF FUNCTIONAL CONFECTIONERY IN 10, 20 AND 30 DAYS, $\mathrm{P}<0,05 \mathrm{~N}=10$

\begin{tabular}{|l|c|c|c|}
\hline \multirow{2}{*}{\multicolumn{1}{|c|}{$\begin{array}{c}\text { Groups } \\
\text { animals' }\end{array}$}} & \multicolumn{3}{|c|}{ Maximum running time } \\
\cline { 2 - 4 } & $\begin{array}{c}\text { after 10 days } \\
\text { uses }\end{array}$ & $\begin{array}{c}\text { after 20 days } \\
\text { uses }\end{array}$ & $\begin{array}{c}\text { after 30 days } \\
\text { uses }\end{array}$ \\
\hline Control & \multicolumn{3}{|c|}{$8.0 \pm 0.28$} \\
\hline $\begin{array}{l}\text { Control + } \\
\text { refrigerator }\end{array}$ & $7.5 \pm 0.42$ & $9.4 \pm 0.32$ \\
\hline $\begin{array}{l}\text { After the use of } \\
\text { functional } \\
\text { confectionery } \\
\text { products' }\end{array}$ & $8.2 \pm 0.25$ & $9.0 \pm 0.26$ & \\
\hline $\begin{array}{l}\text { After the use of } \\
\text { functional } \\
\text { confectionery } \\
\text { products }+ \text { cold }\end{array}$ & $8.5 \pm 0.49$ & $9.0 \pm 0.26$ & $11.1 \pm 0.45$ \\
\hline
\end{tabular}

According to the data presented in table 1, the animals of the control group were able to run for $8.0 \pm 0.28$ minutes, and against the background of cold exposure for $7.5 \pm 0.42$ minutes at a belt speed of $30 \mathrm{~m} / \mathrm{min}$. Inclusion in the diet of iris and dragees increased the duration of the run. A significant increase in the duration of running rats was observed in animals after 30 days of use of functional confectionery products with regular placement of animals in the climate chamber, which was $11.1 \pm 0.45$ minutes, which is 2.6 minutes more than after 10 days of use of functional pills and iris. Criteria maximum performance (physical endurance) also served as the time of swimming to complete exhaustion in the water at a temperature of $38-400 \mathrm{C}$ rats with a load $(10 \%$ body weight). The main signs of fatigue, with the manifestation of which the animals were removed from the pool, were: inability to stay on the metal edging of the aquarium by the front limbs, frequent and prolonged dives to the bottom, "lateral position" after extraction from the water. Swimming technique is more convenient for physical endurance and integral characteristics of the body. Studies the swimming time of rats to complete exhaustion in water after 10,20 and 30 days of consumption of pills and iris functional purpose, 
which were added to the daily diet of $1.5 \mathrm{~g}$, respectively, of each product 3 times a day are shown in figure 2 .

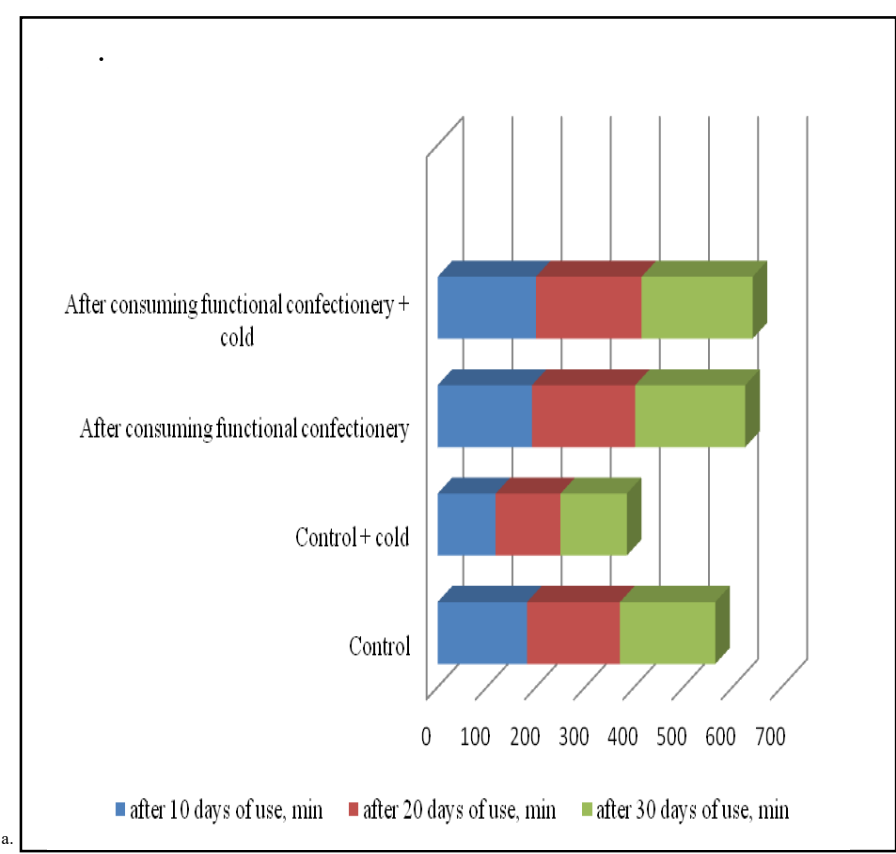

Fig. 2. "Non-specialized process" of updating of complex processing of raw materials.

In the course of the research, the cold effect significantly reduced the resistance to swimming of rats on all days of research on the use of functional confectionery products, leading to increased resistance to fatigue and an increase in the duration of navigation on all days of the experiment. Analyzing the data obtained in Figure 2, the animals in the control group were able to swim for $118 \pm 3.2$ minutes. After consuming functional confectionery products, the tendency to increase the duration of swimming was noted, the maximum value of which was also noted after a thirty day use of functional confectionery products against the background of cold exposure and amounted to $140 \pm 4.5$ minutes, which is 15 minutes less than after a ten-day use. Thus, the analysis of the presented experimental data indicates that the use of functional confectionery products increases the duration of the swimming of rats.

Studies of the use of functional confectionery products against the background of systematically carried out muscular loads, which consisted in determining the maximum duration of running on a treadmill after 10,20,30 days of the experiment are shown in Fig. 3.

The inclusion of functional confectionery in the diet increased the running time, even depending on the time of use in the first and second cases. The most significant increase was observed after a thirty day use of functional confectionery products with regular exposure to cold and was $40.2 \pm 2.5$ minutes, whereas after a twenty-day use this indicator was $36.4 \pm 1.8$ minutes.
Thus, the results of determining the duration of running on the treadmill indicate a decrease in resistance to physical stresses during cold exposure. Depending on the time of consumption of functional confectionery, the indicator studied tended to increase.

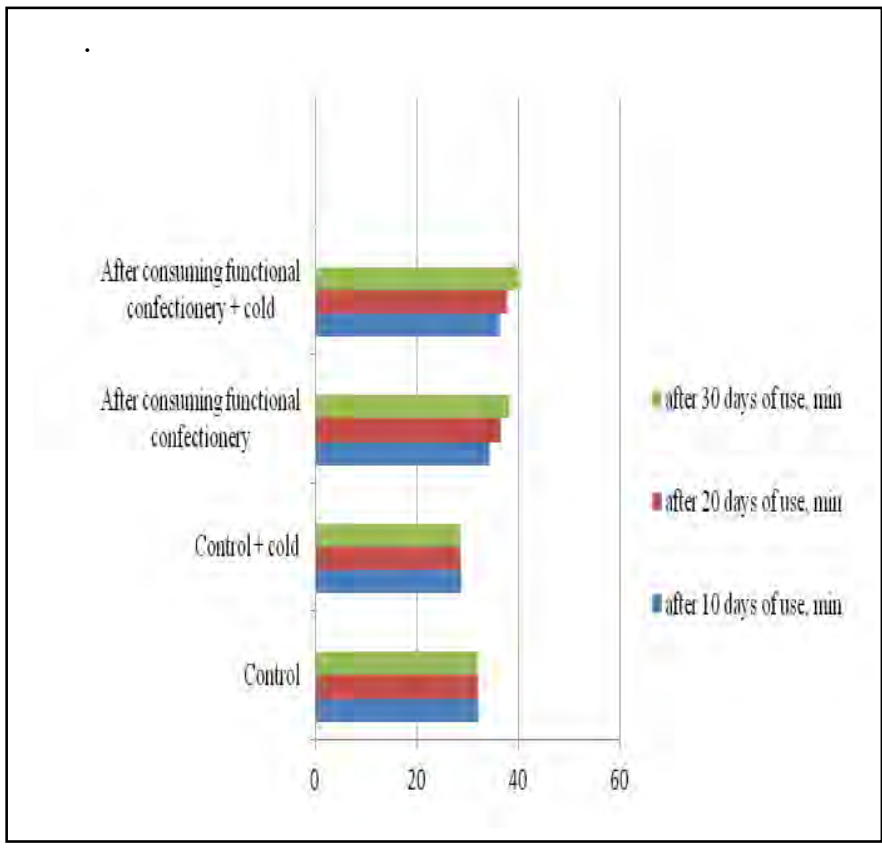

Fig. 3. "Non-specialized process" of updating of complex processing of raw materials.

\section{Acknowledgment}

Thus, the study of plant and animal raw materials and products of their complex processing has revealed a wide range of physiological ingredients, the introduction of which in confectionery products can contribute to the expansion of the range of functional products, the systematic use of which can contribute to the partial satisfaction of the human body's needs in physiologically valuable ingredients (vitamins, phospholipids, polyphenols, etc.)

In the course of research, it was found that cold exposure reduces the resistance of experimental animals to fatigue. Thus, a decrease in the resistance of experimental rats to a dynamic and static load was found-a decrease in the duration of swimming in rats, as well as running on a treadmill and hovering time on a vertical grid. After thirty day use of functional confectionery, all the studied indicators tended to increase. Consequently, the use of functional confectionery products can be recommended for nutrition in order to increase the adaptive capacity of the organism.

I would like to express my gratitude to the Doctor of Technical Sciences, Professor N. Shkrabtak. for advising a part of the work devoted to research on laboratory animals. 


\section{References}

[1] N. Frolova, "Formulation and development of confectionery products for functional nutrition". In international research journal, vol. 1-1(67). pp. 157-160, 2018 - DOI:https://doi.org/10.23670/IRJ.2018.67.084

[2] Sulaiman Mohammed, Hamzat Ibiyeye Tijani, Mohammed Abubakar Bashir, "An overview of natural plant antioxidants: analysis and evaluation". African Journal of Microbiology Research. vol. 1(4) - pp. 64-72, 2013.DOI: :https://doi.org /10.11648/j.ab.20130104.12

[3] N.A. Frolova, N.F. Ivankina, "The use of biologically active additives of plant and animal raw materials of the Far East in the technology of candy caramel". Achievement of science and technology of agriculture. vol. 7. pp. 69, 2010.

[4] V. P. Kolosov, "Epidemiological features and dynamics of respiratory health indicators in the Far East of Russia". Dal nevostochnyy meditsinskiy zhurnal. vol. 1. pp.101-103, 2010

[5] Ed. G. p. Yakovlev, K.F. Blinovoi, "Medical plant raw materials", Pharmacognosy: Proc. allowance. 765 p, 2004.

[6] J. V. Dobrin, "The study of the chemical and elemental composition of the leaves of the Chinese Magnolia vine harvested in the Voronezh region", Chemistry Series. Biology. Pharmacy. vol. 1 . pp. $136-139$, 2016.

[7] J. Namiesnik, M. Kupska, K. Vearasilp, K. S. Ham, S. G. Kang, Y. K. Park, Barasch D., Nemirovski A., Gorinstein S., "Antioxidant activities and bioactive components in some berries", European food research and technology. vol. 5. pp. $819-829,2013$.

[8] Orlin N. Ah, "On biologically active substances of schisandra chinensis", International journal of applied and fundamental research. vol 4. 115 p., 2009

[9] Ele Ekouna, Pau Roblot, Courtois B., Courtois J., "Chemical haracterization of pectin from green tea (Camellia sinensis)", Carbohydrate Polymers.Vol. 83/pp.1232-1239, 2011.
[10] Wong Weng Wai, Abbas Karkhi, Azhar Mat Easa, "Comparing biosorbent ability of modified citrus and durian rind pectin", Carbohydrate Polymers. Vol. 79. pp.584-589., 2010

[11] Bockki Min, Young Bae, Hyeon Gyu Lee, "Utilization of pectin enhanced materials from apple pomace as a fat replacer in a model food system", Bioresource Technology. Vol. 101. pp. 5414-5418., 2010

[12] Y-W Avula, "Quantitative Determination of Lignan Constituents from Schisandra chinensis by Liquid Chromatography", Chromotography. vol 9. pp. 61-66.,2005

[13] Sulaiman Mohammed, Tijani Hamzat Ibiyeye, Abubakar Bashir Mohammed, "An overview of natural plant antioxidants: analysis and evaluation", African Journal of Microbiology Research, vol4. pp. $64-$ 72.,2013 DOI: 10.11648 / j.ab.20130104.12.

[14] U. Vijayalakshmi, Abhilasha Shourie, "Remedy effect of ascorbic acid and citric acid on oxidative browning of Glycyrrhiza glabra callus cultures" vol. 97 (3). $\quad$ pp. 179 - 186, 2016. DOI: https://doi.org/10.5114/bta.2016.62355.

[15] Y.V. Dobrina, "A study of the chemical and elemental composition of Chinese magnolia vine leaves harvested in the Voronezh region", Bulletin of Voronezh State University. Series Chemistry. Biology. Pharmacy. vol.1. pp. 136 - 139., 2016

[16] A. Frati, "Industrial freezing, cooking, and storage differently affect antioxidant nutrients in vegetables", Bioactive Foods in Health Promotion. pp. $23-39,2016$

[17] Corinne Pau'roblot, Bernard Courtois, Josiane Courtois, "Interac'tions between polysaccharides uronic acid sequences and lipid molecules", Vol. 13. pp. $443-448,2010$. 